\title{
Emotional Intelligence and Leadership Styles of Head Nurses at Governmental Hospitals in Port-Said
}

Abeer Wassif Shenouda Wassif, prof. Samia Mohammed Adam, Dr. Fathya Abd ELRazek Afify

B.Sc Nursing Suez Canal University, Professor of Nursing Administration Faculty of Nursing Ain Shams University, Lecturer of Nursing Administration Faculty of Nursing Port Said University

\begin{abstract}
Background: Emotional intelligence (EI) has become a global phenomenon due to its far reaching implications for individuals, groups, society as a whole and it is critical to becoming a successful leader. In addition to effective leadership plays an important role in the growth and better performance of the organization. The aim: of the present study was to assess the relationship between emotional intelligence and leadership styles of the head nurses at governmental hospitals in Port-Said. The research design: was a correlational descriptive design. The subjects of this study consisted of two groups; Head nurses group (31) and staff nurses group (216), two tools were used for data collection as the followings: emotional intelligence questionnaire which used to assess emotional intelligence level of head nurses and leadership styles questionnaire which used to assess leadership styles used by head nurses from staff nurse's point of view. The results: revealed that self-awareness of head nurses scores reported the highest mean percentage compared to self-regulation in personal competence whereas social skills scored the highest mean percentage in social competence and all competence of emotional intelligence and transformational leadership scored the highest mean percentage than transactional leadership in advanced styles and all styles from staff nurse's point of view. The study concluded: that there was no statistically significant correlation between emotional intelligence and leadership styles. However, two skills of transformational styles inspirational motivation and individual consideration had a negative statistically significant correlation with social competence of EI, in addition to, personal competence and total EI was founded for inspirational motivation only. The study recommended: that there are an obvious needs for educate the new head nurses about emotional intelligence competence and how to improve their emotional intelligence orientation with leadership styles by their organization
\end{abstract}

Key words: Emotional Intelligence, Leadership Styles, Head nurses. 


\section{INTRODUCTION}

Nurses, as a major professional force in health care organizations, must manage the emotional aspects resulting from these changes in order to ensure effective organizational outcomes and maintain a high level of emotional health. In addition, nursing is a profession that involves interpersonal relationships on a daily basis, so it is imperative for nurses to understand their own feelings and use them to make good decisions as well as having empathy for others. It is necessary to learn how to vie and understand peoples' behavior, attitude, interpersonal skill and potentialities. The individuals who have these characteristics are said to be emotionally intelligent Molter, (2001).

According to Goleman model, emotional intelligence (EI) consists of five competencies; self awareness, self-regulation, motivation, social competences and empathy. Self-awareness involves doing an accurate self-assessment to know our strengths and weaknesses and an emotional awareness of our emotions and their effects. These help ensure self-confidence about our self-worth and capabilities. Selfregulation involves keeping our disruptive emotions and impulses under control, maintain honesty and integrity, taking responsibility for our own performance, being flexible for handling change, and becoming comfortable with new information and approaches Tomey, 2009; Bach and Ellis, (2011).

In addition, motivation can help us reach goals by striving to meet a standard of excellence, aligning our personal goals with the group and organizational goals, taking advantage of opportunities, and keeping a positive attitude about pursuing despite obstacles and setbacks. Whereas, empathy involves taking an interest in others' concerns and understanding them, anticipating and meeting customers' needs and developing others' abilities. Finally, social skills are proficiency in handling relationships and building networks; and an ability to find a common ground Marquis and Huston, (2009); Tomey, (2009).

Neale et al. (2009) clarified that advantages of developing the human being emotional intelligence (EI) are improved relationships, improved communication with others, better empathy skills, acting with integrity, respect from others, improved career prospects, managing change more confidently, fewer power games at work, feeling confident and positive, reduced stress level, increase creativity, learning from mistakes in addition to increasing orientation towards positive values Akerjordet and Severinsson, (2007).

Health care is facing number of challenges in the twenty-first century. All of these challenges require effective leadership and successful leader able to help people meet all of these challenges. The leader's function is to guide an organization using vision, to make choices based on mutual values, and to engage in the culture to provide meaning and coherence. This type of leadership fosters growth within each of us as individuals and as members of a group Hussein, (2009); Kelly, (2012). Hence, many 
of the characteristics are still used to describe successful leaders today as intelligent, knowledge, emotional intelligence, independence, creativity, cooperativeness, alertness, self-confidence, personal integrity, emotional balance and control, adaptability, social interaction, interpersonal skills, ability and judgment Marquis and Huston, (2009).

Marquis and Huston (2009) clarified that leadership styles started with three leadership styles, which are autocratic, democratic and laissez-faire. In addition, there are two primary types of leaders called transformational and transactional leaders. The autocratic leader makes decisions alone, and tends to be more concerned with task accomplishment than with concern for people. In contrast, the democratic leader involves followers in the decision making process and is people-oriented, focusing on human relations and teamwork. Whereas, the laissez-faire leader is permissive and generally abstains from leading the staff, which often results in low productivity and employee frustration Roussel et al.,(2006). On the other hand, transactional leaders focus on organizational operations and short-term goals. They use exchange and make trades as a way of accomplishing work. Transformational leaders inspire and motivate others to excel and participate in a vision that goes beyond self interests. Transformational leadership is believed to empower followers and contribute to their commitment to action and change (Kelly, 2012).

\section{Significance of the Study}

Alston (2009); Marquis and Huston, (2009) clarified that effective leadership is absolutely critical to organizational success in the twenty-first century and leaders today must have the ability and flexibility to adapt to an ever-changing workforce. These human abilities including emotional intellect, set people apart as successful leaders.Chiva and Alegre (2008) resultsconfirm that EI is becoming one of the most important individual competence for organization and has been theoretically related to organizational performance. However, Smith et al. (2009) ;Feather (2009) clarified the importance of further research related to EI especially that it is a recent phenomenon in nursing research as there are many knowledge gaps related to EI and leadership . In addition, the research on EI is scarce and still at the development stage (Akerjordet and Severinsson, 2007).Consequently, the current research is geared to study emotional intelligence and leadership styles of head nurses at governmental hospitals in Port-Said.

\section{The Aim of the Study:}

To assess the relationship between emotional intelligence and leadership styles of the head nurses at governmental hospitals in Port-Said.this was achieved through:

1. Assess the emotional intelligence level of head nurses at governmental hospitals in Port-Said.

2. Determine leadership styles of head nurses from the staff nurses point of view at governmental hospitals in Port-Said. 
3. Find out the relationship between emotional intelligence of head nurses and their leadership styles at governmental hospitals in Port-Said.

\section{Research Questions:}

1. What is the level of emotional intelligence of head nurses at governmental hospitals in Port-Said?

2. What are the leadership styles of head nurses from staff nurses point of view at governmental hospitals in Port-Said?

3. Is there a relationship between emotional Intelligence of head nurses and their leadership styles?

SUBJECTS AND METHODS

Methods of study were elaborated under four main designs as follows:

1- Technical Design

2- Operational Design

3- Administrative Design

4- Statistical Design

(1) Technical Design: the technical design included the research design, study setting, subjects of the study and tools for data collection.

Research design: Acorrelational descriptive design.

Setting: The study was conducted in three governmental hospitals; namely Port-Said general hospital, Port-Fouad general hospital and El-Zehour general hospital in portSaid governorate affiliated to the ministry of health.

Subjects: the subjects of this study included two groups; namely head nurses group and staff nurses group. Head nurses group included all head nurses (31) and the estimated sample size was 196 staff nurses, after adjustment for a dropout rate of $10 \%$ the sample size was increased to 216 staff nurses. The only inclusion criterion for staff nurses was a work experience in the study setting and work unit for at least one year.

Tools for data collection:-Two tools were used to collect data for this study as follows:

Tool I: Emotional intelligence questionnaire sheet.

It was used to assess the level of emotional intelligence (EI) of head nurses. This tool was divided into two parts:

Part (I): This part included head nurses demographic characteristics as name, age, sector, hospital name, department, qualification, and years of experience.

Part (II): This part used for assessing emotional intelligence level of head nurses. It was adopted by Mahmoud (2002) based on Goleman (1998). This tool consists of 83 items grouped in two categories: personal competence and social competence.

\section{(A) Personal Competence:}

It included 49 items categorized under three divisions namely, self-awareness (15items), self-regulation (17items) and self-motivation(17items).

(B) Social Competence: 
It included thirty-four $\mathbf{3 4}$ items categorized under two divisions, namely; empathy (15items) and social skills (19items).

\section{Scoring System:}

The responses of participants were collected along 5-point Likert scale from completely applicable, frequently apply, sometimes applicable, slightly apply and not applicable (5 to 1 respectively) for each statement. For statistically purpose, the five 5-point Likert scale changed into three scales to become completely applicable, sometimes applicable and not applicable. For each domain of factors, the scores of the items were summed-up for each item and the total divided by the number of the items, giving a mean score for the part. these scores were converted into a percent score, and means and standard deviations were computed. The emotional intelligence was considered to be high if the percent score was $60 \%$ or more , and low if less than $60 \%$ (Abdel-Aleem, 2013).

One item on emotional intelligence statements needed to be reversely scored. It was number "46". If a respondent circled 5 (which is interpreted as completely applicable), it was reversed to 1 (which means not applicable).

\section{Tool II: Leadership Styles Questionnaire}

It was aimed to assess leadership styles used by the head nurses from the point of view of their staff nurses. It was adopted from Hussein (2009) and developing based on Clark (1998); El- Sayed (2005). It was composed of "81" statements under two categories namely; traditional category and advanced category.

\section{(A) Traditional Category:}

It included "24" statements categorized under three divisions namely; autocratic (8 statements), democratic (8 statements), and laissez faire (8 statements).

\section{(B) Advanced Category:}

It included fifty-seven statements categorized under two major divisions, namely transformational and transactional style.

1. Transformational style: Consisted of "38" statements and was subdivided into the following groups: Attributed charisma:(6 statements),idealized influence( 9 statements) ,inspirational motivation( $7 \quad$ statements),intellectual stimulation(8statements), and individual consideration(8 statements).

2. Transactional style: Contained "19" statements subdivided into the following groups:

Contingent reward: (6 statements) ,active management -by- exception (6 statements), and passive management -by- exception: (7 statements).

\section{Scoring System:}

The responses of participants were collected along five point rating scale ranged from "always" to "never" (5 to 1 respectively) for each statements. The scores of each style were summed-up and the total divided by the number of the items, giving a mean score to have the mean percentage of the leadership style. For statistically purpose, the five point rating scale changed into three scales by adding always to usually and rarely to never in data presentation.

(2)Operational Design: included content preparatory stage, validity, and reliability of the tools, pilot study and field work. 
- Preparatory stage: The tools was previously used on Egyptian sample and tested for its validity, applicability and reliability.

- Tools Validity: The intended tools of data collection were revised by the researcher and got supervisor's approval as the tool was previously translated into Arabic, and used on Egyptian and tested for its validity, and applicability

- Reliability of study tools: Cronbach alpha coefficient was calculated to assess the reliability of the tools through their consistency as follows:

Reliability statistics for emotional intelligence for head nurses.

\begin{tabular}{|l|l|l|}
\hline Emotional Intelligence & Number of items & Cronbach's Alpha \\
\hline Personal competence & 49 & 0.874 \\
Self-awareness & 15 & 0.730 \\
Self-regulation & 17 & 0.788 \\
Motivation & 17 & 0.716 \\
\hline Social competence & 34 & 0.874 \\
Empathy & 15 & 0.831 \\
Social skills & 19 & 0.806 \\
\hline Outcome factors & 9 & 0.666 \\
\hline Total Emotional Intelligence & 83 & 0.925 \\
\hline
\end{tabular}

Reliability for leadership styles questionnaire for staff nurses.

\begin{tabular}{|l|l|l|}
\hline Leadership styles & Number of items & Cronbach's Alpha \\
\hline Traditional Styles & 24 & 0.738 \\
Autocratic & 8 & 0.671 \\
Democratic & 8 & 0.640 \\
Laissez-faire & 8 & 0.733 \\
\hline Transformational Dimension & 38 & 0.950 \\
Attributed charisma & 6 & 0.828 \\
Idealized influence & 9 & 0.825 \\
Inspirational motivation & 7 & 0.871 \\
Intellectual stimulation & 8 & 0.860 \\
Individual consideration & 8 & 0.857 \\
\hline Transactional Dimension & 19 & 0.869 \\
Contingent reward & 6 & 0.856 \\
Active management -by-exception & 6 & 0.828 \\
Passive management-by-exception & 7 & 0.757 \\
\hline Advanced leadership & 57 & 0.954 \\
\hline Total Leadership styles & 81 & 0.951 \\
\hline Outcome factors & 9 & 0.697 \\
\hline
\end{tabular}

- Pilot study: A pilot study was carried out on "6" head nurses and "24" staff nurses who represented $10 \%$ of the total sample, from El-Homeate hospital and El-Nasser hospital. The purpose of the pilot study was to test the applicability and feasibility of the study tools. Also it served to estimate the time needed to fill-in the questions, in addition to finding out any obstacles and problems that might interfere with data 
collection. The subjects who shared in the pilot study were excluded from the study subjects and completion of tools took 20-30 minutes for each tool.

- Field work: The data were collected from all head nurses and their staff nurses in the study settings using the questionnaire sheets. This process of data collection was carried out in the period from Mid-May 2013 to Mid-September 2013.The study tools were distributed to the selected subjects in their work setting by the researcher. Data were collected by the researcher from head nurses in the morning shift and their nurses at five days per week in three shifts. While night shifts, the questionnaires were obtained during the morning shift after explaining the objectives of the study and how to complete the tool. Some of the participants filled in the questionnaire sheets at the time of distribution, while others fixed another time to fill them. Data were collected by the researcher over 4 month's period.

(3) Administrative Design: An official letters directed from the Dean of Faculty of Nursing in Port-Said University to medical and nursing directors of the studied hospitals to obtain formal agreement of each hospital director for conducting this study. On data collection, a verbal agreement of participation was taken from head nurses and staff nurses involved in this study, after explaining the purpose of this study for the participant.

- Ethical Consideration:A brief explanation of the aim of the study was given to director, head nurses, and staff nurses in the study, stressing on confidentiality of the collected information to be familiar with the importance of their participation and it is only for the purpose of the study to take their formal agreement for included in the study. And they were informed about their right to refuse or to withdraw at any time.

(4) Statistical Design: Statistical Analysis of the Data

Data entry and statistical analysis were done using IBM SPSS software package version 20.0.Qualitative data were described using number and percent. Quantitative data were described using mean and standard deviation for normally distributed data. Comparison between different groups regarding categorical variables was tested using Chi-square test. The distributions of quantitative variables were tested for normality using KolmogorovSmirnov test, Shapiro-Wilk test and D'Agstino test, also Histogram and QQ plot were used for vision test. If it reveals normal data distribution, parametric test wasapplied. If the data were abnormally distributed, non-parametric test was used. For normally distributed data, comparison between different groups was analyzed using F-test (ANOVA). Correlations between two quantitative variables were assessed using Pearson coefficient. Significance test results were quoted as two-tailed probabilities. Significance of the obtained results was judged at the $5 \%$ level (Leslie et al., 1991; Kotz et al., 2006;

Kirkpatrick and Feeney, 2013).

\section{RESULTS:}

Table (1) : shows the distribution of studied head nurses according to demographic characteristics .It was found that the highest percentage (32.3\%) of head nurses had age 50 years old or more, with a mean age $(43.67 \pm 10.45)$ years. In addition, most of head nurses $(74.2 \%)$ had nursing school diploma, the highest percentage $(38.7 \%)$ of them were from Port-Fouad general hospitals and the same percent worked at 
economic department. Whereas, more than half of head nurses (58.1\%) had more than 20 years of experience, with a mean experience of $(22.23 \pm 10.63)$ years.

Table (2): shows the distribution of studied staff nurses according to demographic characteristics. It was found that the highest percentages of the staff nurses (51.6\%) had aged less than 30 years old, with a mean age (32.89 \pm 9.9$)$ years. In addition, $(88.5 \%)$ of staff nurses had nursing school diploma, the highest percentages of them (39.2\%) were from Port-Fouad general hospital and (38.7\%) worked at economic department. Whereas, more than one fifth $(24.4 \%)$ of them had 6-10 years of experience, with a mean experience of $(13.74 \pm 9.30)$ years.

Table (3): shows the mean percentage of emotional intelligence level of head nurses at governmental hospitals. It was found that self-awareness scored the highest mean percentage $(87.52 \% \pm 11.54)$ compared to self-regulation in personal competence $(82.06 \% \pm 14.33)$ whereas social skills scored the highest mean percentage $(88.53 \%$ \pm 11.05 ) in social competence and all competence of emotional intelligence.

Table (4): shows mean percentage of leadership styles of head nurses from the point of view of staff nurses at governmental hospitals. It was found that transformational leadership $(72.48 \% \pm 21.57)$ scored the higher mean percentage than transactional leadership (62.47\% \pm 21.67$)$ in advanced styles and all leadership styles.

Table (5): shows the correlation between emotional intelligence and leadership styles from the point of view of staff nurses at governmental hospitals. It was found that there was no statistically significant correlation between EI and leadership styles. However, two skills of transformational styles inspirational motivation and individual consideration had a negative statistically significant correlation with social competence of EI in addition to personal competence and total EI for inspirational motivation only. 
Table (1): Distribution of studied head nurses accordingto demographic characteristics $(\mathrm{N}=31)$.

\begin{tabular}{|c|c|c|}
\hline Socio demographic Characteristics & No. & $\%$ \\
\hline $\begin{array}{l}30-< \\
30- \\
40- \\
\geq 50\end{array}$ & $\begin{array}{l}4 \\
8 \\
9 \\
10\end{array}$ & $\begin{array}{l}12.9 \\
25.8 \\
29.0 \\
32.3\end{array}$ \\
\hline Mean \pm SD & \multicolumn{2}{|c|}{$43.67 \pm 10.45$} \\
\hline \begin{tabular}{l}
\multicolumn{1}{c}{ Qualification } \\
Nursing school diploma \\
Health Technical \\
BSC of Nursing
\end{tabular} & $\begin{array}{l}23 \\
2 \\
6 \\
\end{array}$ & $\begin{array}{l}74.2 \\
6.5 \\
19.4 \\
\end{array}$ \\
\hline $\begin{array}{l}\text { Hospital } \\
\text { Port- Said General } \\
\text { Port- Fouad General } \\
\text { El - Zohor General }\end{array}$ & $\begin{array}{l}11 \\
12 \\
8\end{array}$ & $\begin{array}{l}35.5 \\
38.7 \\
25.8\end{array}$ \\
\hline $\begin{array}{l}\quad \text { Department } \\
\text { Economic Department } \\
\text { Free Department } \\
\text { Out-Patient Clinics }\end{array}$ & $\begin{array}{l}12 \\
17 \\
2 \\
\end{array}$ & $\begin{array}{l}38.7 \\
55 \\
6.5 \\
\end{array}$ \\
\hline $\begin{array}{l}\leq 5 \\
\leq 5-10 \\
6-15 \\
11-15 \\
16-20 \\
>20\end{array}$ & $\begin{array}{l}3 \\
3 \\
4 \\
3 \\
18\end{array}$ & $\begin{array}{l}9.7 \\
9.7 \\
12.9 \\
9.7 \\
58.1\end{array}$ \\
\hline Mean \pm SD & \multicolumn{2}{|c|}{$22.23 \pm 10.63$} \\
\hline
\end{tabular}


Table (2): Distribution of studied staff nurses accordingto demographic characteristics $(\mathrm{N}=31)$.

\begin{tabular}{|c|c|c|}
\hline Socio demographic characteristics & No. & $\%$ \\
\hline $\begin{array}{l}\text { Age } \\
\qquad \begin{array}{l}<30- \\
30- \\
40-\geq 50\end{array}\end{array}$ & $\begin{array}{l}112 \\
60 \\
31 \\
14\end{array}$ & $\begin{array}{l}51.6 \\
27.6 \\
14.3 \\
6.5\end{array}$ \\
\hline Mean \pm SD & \multicolumn{2}{|c|}{$32.89 \pm 9.9$} \\
\hline $\begin{array}{l}\text { Qualification } \\
\text { NursingSchool Diploma } \\
\text { Health Technical } \\
\text { BSC of Nursing }\end{array}$ & $\begin{array}{l}192 \\
15 \\
10\end{array}$ & $\begin{array}{l}88.5 \\
6.9 \\
4.6\end{array}$ \\
\hline $\begin{array}{l}\text { Hospital } \\
\text { Port- Said General } \\
\text { Port- Fouad General } \\
\text { El - Zohor General }\end{array}$ & $\begin{array}{l}76 \\
85 \\
56\end{array}$ & $\begin{array}{l}35.0 \\
39.2 \\
25.8\end{array}$ \\
\hline $\begin{array}{l}\text { Department } \\
\text { Economic Department } \\
\text { Free Department } \\
\text { Out-Patient Clinics }\end{array}$ & $\begin{array}{l}84 \\
119 \\
14\end{array}$ & $\begin{array}{l}38.7 \\
55 \\
6.5\end{array}$ \\
\hline $\begin{array}{l}\text { Experience } \\
\leq 5 \\
6-10 \\
11-15 \\
16-20 \\
>20\end{array}$ & $\begin{array}{l}46 \\
53 \\
38 \\
28 \\
52\end{array}$ & $\begin{array}{l}21.2 \\
24.4 \\
17.5 \\
12.9 \\
24.0\end{array}$ \\
\hline Mean \pm SD & \multicolumn{2}{|c|}{$13.74 \pm 9.30$} \\
\hline
\end{tabular}

Table (3): Mean percentage of emotional intelligence level of head nurses at governmental hospitals $(n=31)$.

\begin{tabular}{|l|l|}
\hline Emotional Intelligence & Mean $\% \pm$ SD \\
\hline Self-awareness & \\
Self-regulation & $87.52 \% \pm 11.54$ \\
Self-motivation & $82.06 \% \pm 14.33$ \\
Personal competence & $86.05 \% \pm 10.32 \mathbf{8 5 . 1 2 \%} \pm \mathbf{1 0 . 0 6}$ \\
\hline Empathy & \\
Social skills & $86.23 \% \pm 13.87$ \\
Social competence & $88.53 \% \pm 11.05$ \\
\hline Total Emotional Intelligence & $\mathbf{8 7 . 5 2 \%} \pm \mathbf{1 0 . 7 3}$ \\
\hline
\end{tabular}


Table (4): Mean percentage of leadership styles of head nurses from the point of view of staff nursesat governmental hospitals $(\mathrm{n}=217)$

\begin{tabular}{|l|l|}
\hline Leadership Styles & Mean\% $\mathbf{\text { SD }}$ \\
\hline Autocratic Style & $59.97 \% \pm 20.10$ \\
Democratic Style & $68.84 \% \pm 19.36$ \\
Laissez-faire Style & $66.47 \% \pm 22.81$ \\
Total Traditional Styles & $\mathbf{6 5 . 0 9} \% \pm \mathbf{1 4 . 5 0}$ \\
\hline Attributed charisma & $78.92 \% \pm 24.41$ \\
Idealized influence & $72.73 \% \pm 23.18$ \\
Inspirational motivation & $73.70 \% \pm 27.29$ \\
Intellectual stimulation & $68.55 \% \pm 27.0$ \\
Individual consideration & $70.25 \% \pm 26.73$ \\
Transformational Dimensions & $\mathbf{7 2 . 4 8} \% \pm \mathbf{2 1 . 5 7}$ \\
\hline Contingent reward & $66.32 \% \pm 29.62$ \\
Active management-by-exception & $70.55 \% \pm 27.35$ \\
Passive management-by-exception & $52.24 \% \pm 26.98$ \\
Transactional Dimensions & $\mathbf{6 2 . 4 7} \% \pm \mathbf{2 1 . 6 7}$ \\
\hline Total Advanced Styles & $\mathbf{6 9 . 1 4} \% \pm \mathbf{1 9 . 7 9}$ \\
\hline
\end{tabular}

Table (5): Correlation between emotional intelligenceand leadershipstyles from the point of view of staff nurses $(n=216)$.

\begin{tabular}{|l|l|l|l|}
\hline \multirow{2}{*}{ Leadership styles } & $\begin{array}{l}\text { Personal } \\
\text { Competen } \\
\text { ce }\end{array}$ & $\begin{array}{l}\text { Social } \\
\text { competenc } \\
\text { e }\end{array}$ & $\begin{array}{l}\text { Emotional } \\
\text { intelligence }\end{array}$ \\
\cline { 2 - 4 } & $\mathbf{R}$ & $\mathbf{R}$ & $\mathbf{R}$ \\
\hline Autocratic & 0.218 & 0.175 & 0.213 \\
\hline Democratic & -0.012 & -0.010 & -0.012 \\
\hline Laissez-faire & -0.073 & -0.215 & -0.142 \\
\hline Traditional Styles & 0.074 & -0.008 & 0.042 \\
\hline Attributed charisma & -0.250 & -0.193 & -0.241 \\
\hline Idealized influence & 0.049 & -0.102 & -0.016 \\
\hline Inspirational motivation & $-0.360^{*}$ & $-0.480 *$ & $-0.440^{*}$ \\
\hline Intellectual stimulation & -0.186 & -0.336 & -0.268 \\
\hline Individual consideration & -0.184 & $-0.360^{*}$ & -0.227 \\
\hline Transformational Styles & -0.200 & -0.335 & -0.276 \\
\hline Contingent reward & -0.062 & -0.102 & -0.084 \\
\hline Active management by -exception & -0.015 & -0.195 & -0.098 \\
\hline Passive management by- exception & 0.154 & 0.087 & 0.134 \\
\hline Transactional Styles & 0.035 & -0.094 & -0.021 \\
\hline
\end{tabular}




\section{DISCUSSION:}

EI is mandatory for leaders of organizations to generate, and then maintain personal and social environment productivity. Only the individuals who can maintain emotionally personal and social environment intelligent can be an effective and efficient leader in accomplishing both personal and organizational goals inducing uniqueness (Venkatesh and Balaji, 2011).

This study was conducted to assess the relationship between emotional intelligence and leadership styles of the head nurses at governmental hospitals in Port-Said.

The results of the present study showed that the highest percentages of head nurses had a mean age of $(43.67 \pm 10.45)$ years and mean years of experience of (22.23 \pm 10.63$)$. This may mean that the head nurses with middle aged have multiple life experiences through frequent interactions with others, these interactions make them more knowledgeable and aware of the feelings of others and this may affect positively on emotional intelligence. In this regard, Codier et al. (2008) mentioned that age has been found to correlate with EI score. While these findings contrast with Day and Carroll (2004); Munroe (2009) who stated that younger individuals tended to be better than older individuals at perceiving emotions and the total years of experience has no significant effect on EI.

Regarding socio demographic data for staff nurses, the findings of the present study indicated that the highest percentage of staff nurses from Port-Fouad general hospitals had a mean age of $32.89 \pm 9.9$ years with $13.74 \pm 9.30$ years of experience. This may be due to staff nurses, in adulthood stage with their years of experience have the tendency to become enthusiastic to work, especially when head nurses are transformational leader.

Regarding the total emotional intelligence of head nurses at governmental hospitals, the findings of the present study illustrated that head nurses have high emotional intelligence competences (self-awareness, self-regulation, motivation, empathy and social skills).This finding was supported by Feather (2009) who indicated that leaders of health care have high EI relating to the nature of the profession. In the same context, this finding was congruent with a study carried out by $\boldsymbol{E L}$-Bakshwan (2004) on EI among nursing supervisor in Tanta University Hospitals. Who reported that nursing supervisors got high mean score in interpersonal connections or relations developer competency. Helaly (2013) added that the majority of nurses in Mansoura University Hospital had a proficient level in all components of emotional intelligence. The findings of the present study showed that self-awareness scored the highest mean percentage compared to self-regulation in personal competence whereas social skills scored the highest mean percentage in social competence and all competence of emotional intelligence. This may be attributed to that social skills is one of the required skills in nursing practicing skills as it is practiced daily with each work rather than other skills of EI and it is leading to greater adaptability and improved relationships in nursing, increased orientation towards positive attitudes and values. 
Low EI puts up a barrier for a good interpersonal relationship (Akerjordet and Severinsson, 2007; Far et al., 2014).

This is congruent with Lucas et al (2008) who reported that nursing leaders were rated highest on social awareness. Also, Kooker et al (2007) asserted that social awareness was the most commonly demonstrated domain. Also, Montes-Berges and Augusto (2007) who found that nurses who demonstrated strong, positive coping skills also demonstrated high EI. The results indicated positive correlations between emotional intelligence and social support, social support and repair also one benefit of high EI are the ability to cope with stress in a non destructive manner. Also, this is supported by Dasborough and Ashkanasy (2002); Rahim and Minors (2003) have already argued that leader-member exchange relationship quality is enhanced through EI, and organizations should seek to improve the deficient abilities of managers and assess employees' skills by focusing on honing self-regulation and self-awareness.

On the other hand, Bjerkness and Paranica (2002) stated that emotionally intelligent interactions with other people depend and build on an individual's strengths in self awareness and self management. Without a solid base of self-understanding, self control and adaptability, it is virtually impossible to be open to others and be constructive in work relationship.

Another interpretation of the findings of the present study is that head nurse's workings at governmental hospitals always try to be in touch with other individuals with good communication skills and increase collaboration with them. In addition, they have the ability to understand, assess your emotions and know their strengths and weaknesses but they haven't the ability in controlling emotions in some situations. This may lead to in effective emotional intelligence in the work place and decreased quality of health care.

In this regard, Mayer et al. (2004) asserted that EI and appropriately regulated emotions in the work place are thought to result in delivery of higher-quality health care, enhanced health and improved work performance. Far et al. (2014) clarified that EI consists of broad range of skills, among which social skills and impulsivity control are the most basic and prominent ones. Regarding mean percentage of leadership styles of head nurses from the point of view of staff nurses at governmental hospitals, the findings of the present study revealed that transformational leadership scored the higher mean percentage than transactional leadership in advanced styles and all styles. This finding goes in the same line with El-Sayed (2005); Ali et al. (2013) who stated that the transformational leadership has the higher mean percentages than transactional leadership.

These results are supported by Wood (2003); Hussein (2009) who reported that the prior leadership researches have focused primarily on transformational leadership, and effective successful head nurses as nurse leaders use transformational leadership behaviors more often than transactional leadership. Also, this finding is congruent 
with Avolio and Bass (2004); Bowles and Bowles (2000) who revealed that transformational nursing leaders produce greater effects, most active form of leadership and satisfy to their staff than transactional leadership. Whereas the finding of the present study is contradicting with Amirul and Daud (2012) who stated that leaders at all position levels demonstrated transactional leadership style and the highest means for all level of leaders' positions was transactional leadership followed by transformational leadership. While, Stordeur et al. (2000) reported that there are no consecutive effect of transformational leadership in nursing department.

Regarding correlation between emotional intelligence and leadership styles from the point of view of staff nurses at governmental hospitals, the present study showed that there is no statistically significant correlation between EI and leadership styles especially traditional styles and transactional styles. This is may be as a result of that traditional managers separate any emotion from work place(Goleman et al., 2002), and the transactional leader may lack empathy, which is an important aspect of EI (McKenzie ,2010).

The present study contradicts with Bardzil and Slaski (2003) who stated that organizational policies that reward employee behavior based on EI and treat employees as internal customers result in a climate for services regarded as excellent by staff nurses. In this regard, Venkatesh and Balaji (2011) clarified that leaders may find professional advantage in reflecting on the organizational policies and practices that they oversee, and make a conscious effort to instill EI in those practices. Hence, the emotional intelligence influences and assists effective and efficient leadership of excellence. Also, the present study revealed that there is no statistically significant correlation between EI and transformational styles except two skills of transformational styles inspirational motivation of transformational leadership had statistically negative significant correlation with EI and its competence. In addition, individual consideration only had statistically negative significant correlation with social competence. This isn't in agreements with Rodrigues (2013) who stated that there is a positive relationship between transformational leadership and EI. In addition, McKenzie (2010) stated that managers with EI exhibit the qualities of a transformational leader, and the use of traits, such as motivation, inspiration, and empathy, points to a relationship between transformational leadership and EI.

The present study results disagree with Mandell and Pherwani (2003), who asserted that leaders who aim for a transformational leadership style rich in EI, one which "generates an awareness of the mission or vision of oneself and also to the organization, and develops followers to higher levels of ability and potential", emotional intelligence with rising leadership levels knowing that EI is tied to successful leadership. It follows that skills of emotionally intelligent people like flexibility, conflict management, persuasion and social reasoning, become increasingly important with advancing levels in leadership hierarchy.

In this respect, Barbuto and Burbach (2006);Aydogdu and Asikgil, (2011) who stated that there is need for organizations to address employee satisfaction, organizational 
commitment. The success and competing power of organizations depend on the commitment of their members, supporting their individual developments; these can be achieved with a leader who has good communication skills and high charisma. Also, it is important to have a leader who is the source of inspiration, and intellectual and effective leaders also exhibit high levels of transformational leadership.

Moreover, Amirul and Daud (2012) stated that transformational leaders rely on empathy to understand the way followers' think, feel, and points of view. Personal strengths include the ability to motivate others to reach goals, considered to be emotionally intelligent, including self-control, zeal and persistence, and the ability to motivate oneself.In this respect,Rodrigues (2013)stated that transformational leadership is based more on emotions and hence the leaders having that kind of approach will be more emotionally intelligent than their transactional counterparts.

Also, these results contradict with Goleman et al. (2002) who turn to describe successful leadership traits, their descriptions portray leaders who are aware and have an understanding of their own and other's emotions, and are able to use that understanding to effectively motivate, inspire, challenge, and connect with others; an approach aligned with the transformational style of leadership.

The present study may mean that although head nurses scored the highest mean percentages in personal and social competence of EI with leadership styles, yet they may be not effective emotionally for staff nurses because they may have emotional intelligence as congenital instinct and they acquired EI by life experiences through frequent interaction with others and increased age. In addition, most of head nurses had nursing diploma. So, they needed to train and learn how to use emotions effectively by developing their EI in the field of health care environment more realistically to have strong EI and build successful nursing leadership.

This is assured by Rodrigues (2013) who stated that even organizations can make use of EI and teach their leaders to be more effective. Also, this interpretations is congruent also with Freshman and Rubino (2002); Lucas et al. (2008) who stated that EI is not a fixed trait, but a skill that may be cultivated through careful training to develop skills and the field of health care administration required managers with high EI to possess strong EI and develop positive relationships with staff nurses and were better able to manage emotions in the work place. It is important to learn how to use emotions effectively by developing emotional intelligence. The contemporary concept of EI as a critical set of management skills is traced through time to its current application for health care administration. (Freshman and Rubino, 2002).

Also, Fambrough and Hart (2008) demonstrated that organizations investing resources in cultivating EI through training could expect an increase in work performance. Human resource professionals and trainers might consider implementing policies and procedures that recognize EI as a key ingredient in inducing genuine leadership for organizational success (Venkatesh and Balaji, 2011). 
EI competencies are being viewed as skills to be developed rather than personality traits that are considered less malleable (Freshman and Rubino, 2002).

In this regard, Freshwater and Stickley, (2004) suggest that emotional intelligence should be more realistically and appropriately integrated into the nursing profession by nurse education. Today, emotional intelligence is probed as an important characteristic for building successful nursing leadership(Maulding, 2002; VitelloCicciu, 2002). This is supported by Reeves (2005) who suggested that nurses are in the unique position to influence health in the work force in order to maximize this positive health influence. Also, Bardzil and Slaski (2003); Rahim and Minors (2003) stated that nurses should develop the skills of emotional intelligence. In addition, infusing EI into workplace policies, procedures and conducting EI training for staff will improve organizational service climate, quality assurance of products and services across the board, and enhance manager's problem solving capacity.

This interpretation was assured also by Tucker et al. (2000) who stated that EI is a strong requisite for effective leadership; In order to personally improve emotional intelligence one must find ways to incorporate emotional intelligence skills into one's personal toolbox . For enhanced career success, one must be able to "monitor emotions in self and others, to discriminate among emotions, and manage one's own emotions, being more sensitive by interpreting emotional cues of others is necessary. The recognition of EI in a potential leader is the first step to designing a plan to strengthen that individual's leadership potential (Fambrough and Hart, 2008).

\section{CONCLUSION:}

Based on the findings of the present study, it can be concluded that: there was a high level of EI among head nurses at governmental hospitals in Port-Said. In addition, transformational leadership is the highest used leadership style than transactional in advanced styles and all styles. Finally, there was no significant correlation between EI and leadership styles. However, two skills of transformational styles inspirational motivation and individual consideration had a negative statistically significant correlation with social competence of EI, in addition to, personal competence and total EI for inspirational motivation only.

\section{RECOMMENDATIONS:}

An orientation competence should provide the new head nurses about emotional intelligence and how to improve their EI with leadership styles by their organization to positive outcomes, such as improved employee cooperation and the satisfactory performance of customer service duties. In addition, the study strongly recommends the emerging transformational style; this is more practical, efficient as well as applicable than transactional leadership in advanced styles and all leadership styles. 


\section{REFERENCES:}

Abdel-Aleem, M.M.(2013): Relationship between emotional intelligence,conflict resolution style and group cohesiveness among nurses.Unpublished Doctorate Thesis,Nursing Administration,Faculty of Nursing,Port-Said University,Egypt.p.44

Akerjordet, K. and Severinsson, E. (2007): Emotional intelligence: A review of the literature with specific focuses on empirical and epistemological perspectives. Journal of Clinical Nursing, 16 (8): 1405-1416.

Ali, A.Y.S., Sidow, M.A. and Guled, H.S. (2013): Leadership styles and job satisfaction: Empirical evidence from Mogadishu Universities. European Journal of Management Sciences and Economics,1(1):1-10.

Alston, B.A. (2009): An examination of the relationship between emotional intelligence and leadership practices. Published doctorate thesis, faculty of Business Administration, Vova Southeastern University ; 1-126.

Amirul, SH.R. AndDaud, H.N. (2012): A study on the relationship between leadership styles and leadership effectiveness in Malaysian GLCS. European Journal of Business and Management, 4(8):1-10.

Avolio, B.J. and Bass, B.M. (2004): Multifactor leadership questionnaire: Third edition manual and sampler set. Redwood City, CA: Mind Garden. Published by Mind Garden, Inc.p.28

Aydogdu, S. and Asikgil, B. (2011): The effect of transformational leadership behavior on organizational culture: An application in pharmaceutical industry. International Review of Management and Marketing. 1 (4): 65-73.

Bach, S. and Ellis, P. (2011): Leadership, management and team working in nursing. Great Britain: Learning Matters Ltd.15-20

Barbuto, J.E. and Burbach, M.E. (2006): The emotional intelligence of transformational leaders: A field study of elected officials. The Journal of Social Psychology, 146 (1):51

Bardzil, P. and Slaski, M. (2003): Emotional intelligence: Fundamental competencies for enhanced service provision, managing service quality, 13 (2):97-104.

Bjerkness, D. and Paranica, K. (2002): Training emotional intelligence for conflict resolution practitioners. Available at: http\|www.mediate.com|index.cfm 
Bowles, A. and Bowles, N.B. (2000): A comparative study of transformational leadership in nursing development units and conventional clinical setting. Journal of Nursing Management,8(2):69-76.

Chiva, R. and Alegre, J. (2008): Emotional intelligence and job satisfaction: The role of organizational learning capability. Personal Review, 37(6):680-701.Available at www.emeraldinsight.com 0048-3486.htm

Clark, D. (1998): Leadership style survey: leadership styles.18:10-13. Retrieved in Jun .18, 2011, from http://www.nwlink.com/ donclark/leader/survstyl.html.

Codier, E., Kooker, B.M. and Shoultz, J. (2008): Measuring the emotional intelligence of clinical staff nurses: An approach for improving the clinical care environment. Journal of Nursing Administration Quarterly; 32 (1): 8-14.

Dasborough, M.T.M. and Ashkanasy, N.M. (2002): Emotion and attribution of intentionality in leader-member relationships. The Leadership quarterly, 13(5): 615634.

Day, A.L. and Carroll, S.A. (2004): Using an ability-based measure of emotional intelligence to predict individual performance, group performance, and group citizenship behaviors. Journal of Personality and Individual Differences, 36:14431458 .

El-Bakshawn, Z. (2004): Emotional intelligence leadership skill among nursing supervisors. Unpublished master Thesis in Nursing Administration, Faculty of Nursing, Tanta University.55-70

El-Sayed, K. A. (2005): Leadership style, empowerment and job satisfaction among nursing leaders. Unpublished doctorate Thesis, Nursing Administration, Faculty of Nursing, Ain Shams University, Egypt.122-130

Fambrough, M. and Hart, R. (2008): Emotions in leadership development: A critique of emotional intelligence advances in developing human resources, International Journal of Organizational Behavior and Human Resource Management 10(5): 740-750.

Far, N.S., Samarein, Z.A., Yekleh, M., Tahmasebi, S. and Yaryari, F. (2014): Relationship between the components of emotional intelligence and internet addiction of students in Kharazmi University. International Journal of Psychology and Behavior Research,3(1):60-66. 
Feather, $\boldsymbol{R}$. (2009): Emotional intelligence in relation to nursing leadership: Does it matter?.Journal of Nursing Management, 17,(3): 376-382.

Freshman, B. and Rubino, L. (2002): Emotional intelligence: A core competency for health care administrators. The Health Care Manager, 20(4): 1-8.

Freshwater, D. and Stickley, T.H. (2004): The heart of the art: Emotional intelligence in Nurse Education. Nursing Inquiry. 11(2); 91-98.

Goleman, D. (1998): Working with emotional intelligence. New York: Bantam Books.

In Goleman, D., Boyatzis, R. and McKee,(2002): A Primal Leadership: Realizing the Power of emotional intelligence, Harvard business school Press, Boston, MA.

Helaly,S.H.(2013):Emotional intelligence and its relation to nursing performance among nurses at Mansoura University Hospital and urology and nephrology center (unpublished Doctorate's) Mansoura University, Egypt.p.p105

Hussein, A.A.A. (2009): Relationship between leadership styles and span of control of the head nurses at Zagazig University hospitals ,Unpublished master thesis, Zagazig faculty, Egypt.122-140

Kelly, P. (2012): Nursing leadership and Management: Emotional intelligence. $3^{\text {rd }}$ ed., United States of America: Books World, 12-13.

Kirkpatrick, LA. And Feeney, B.C. (2013): A simple guide to IBM SPSS statistics for version 20.0. Student ed. Belmont, Calif.: Wadsworth, Cengage Learning. 12, p. p115.

Kooker, B.M., Shoultz, J. And Coder, E.E.(2007): Identifying emotional intelligence in professional nursing practice. Journal of Professional Nursing 123(1), 30-36

Kotz, S., Balakrishnan, N., Read, CB. And Vidakovic, B. (2006): Encyclopedia of statistical sciences. $2^{\text {nd }}$ ed., Hoboken, N.J..Wiley-Interscience inc.p.15

Leslie, E., Geoffrey, J. and James, M. (1991): Statistical analysis. In: Interpretation and uses of medical statistics, 4th ed . Oxford scientific publications .pp.411-6.

Lucas, V., Laschinger, H.K.S. and Wong, C.A. (2008): The Impact of emotional intelligent leadership on staff nurse empowerment: The moderating effect of span of control. Journal of Nursing Management. 16 (8): 964-973. 
Mahmoud, A.A.A. (2002): Emotional intelligence for students' university and their relation for it's' and the relation with some knowledge and moods variables, Unpublished thesis ,Helwan faculty,P.p. 267 - 274.

Mandell, B. and Pherwani, S. (2003): Relationship between emotional intelligence and transformational leadership style: A gender comparison, Journal of Business and Psychology, 17 (3): 387-404.

Marquis, B.L. and Huston, C.J. (2009): Leadership roles and management functions in nursing; Theory and application. $6^{\text {th }}$ ed., China :Books World ,38-42.

Maulding,W.S. (2002): Emotional intelligence and successful leadership: Journal Educational and Adminstration,4(6):1-17

Mayer, B.B., Fletcher, T.B. and Parker, S.J. (2004): Enhancing emotional intelligence in the health care environment: An exploratory study. Journal of The Health Care Manager, 23(3):225-234.

Mckenzie, K.L. (2010): Leading an organization through change using emotional intelligence. Published doctorate thesis in Organizational leadership management, Faculty of Philosophy, Phoenix University, 164

Molter, N. (2001): Emotion and emotional intelligence in nursing leadership. Published doctorate thesis in philosophy, Fielding Graduate Institute.214-232.

Montes-Berges, B. and Augusto, J. (2007): Exploring the relationship between perceived emotional intelligence coping, social support and mental health in nursing students. Journal of Psychiatric and Mental Health Nursing, 14(2):163-171.

Munroe, M.D. (2009): Correlation of emotional intelligence and instructional leadership behaviors. Published doctorate thesis in education, University of Phoenix.151pages; 3401625

Neale, S., Spencer-Arnell, L. and Wilson, L. (2009):Emotional intelligence coaching: Improving performance for leaders, coaches and the individual. $1^{\text {st }}$ ed., Great Britain and The United States: Books world, 7-8.

Reeves, A. (2005): Emotional intelligence: Recognizing and regulating emotions. AAOHN Journal, 53(4): 6-172.

Rehim, M.A. and Minors, P. (2003): Effects of emotional intelligence on concern for quality and problem solving. Managerial Auditing Journal, 18(2): 150-155. 
Rodrigues, V. (2013): Emotional intelligence and gender dependent leadership .Pacific Business Review International, 5 (12): 35-37.

Roussel, L., Swansburg, R.C. and Swansburg, R.J. (2006): Management and leadership for nurse a administrators, $4^{\text {th }}$ ed., Boston, London, Jones and Bartlett Publishers,P.p.29-41,199-208.

Smith, K.B., Profetto-McGrath, J. and Cummings, G.G. (2009): Emotional intelligence and nursing: An integrative literature review. International Journal of Nursing Studies, 46:1624-1636. Available at journal homepage: www.elsevier.com/ijns

Stordeur, S.,Vandenberghe, G. and D'hoore, W. (2000): Leadership styles Across Hierarchical levels in Nursing Departments. Nursing Research,49(1):37-43.

Tomey, A. (2009):Guide to nursing management and leadership ,8 th ed,Canada, Mosby, Elsevier, 316-318.

Tucker, M.L., Sojka, J.Z., Barone, F.J. and McCarthy, A.M. (2000): TrainingTomorrow's leaders: Enhancing the emotional intelligence of business graduates. Journal of education for business, 75(6) :331.

Venkatesh, D.R..J. and Balaji, M.R.D. (2011): Emotional intelligence enhances unique leadership. International Journal of Multidisciplinary Management Studies,1(3):1-7.

Vitello-Cicciu, J.M. (2002): Exploring emotional intelligence : Implications for nursing leaders . Journal of Nursing Administration, 32(4):203-210.

Wood, G.M. (2003): Authentic Leadership: Do We Really need another leadership theory? , Published Doctorate's thesis, George Mason University, Virginia, USA.1129

Retrieved from: Http://www.Digilib.Gmu.Edu. 
الأكاء العاطقى وأنماط القياده لمشرفات التمريض بالمستثفيات الحكوميه ببورسعيد

عبير واصف شنودة واصف ،أ.د/ سامية محمد أدم ، د/فتحية عبد الرازق أخصائى تمريض، أستاذ إدارة التمريض-كلية التمريض-جامعة عين شمس ولئ

كمدرس إدارة التمريض- كلية التمريض- جامعة قناة السويس

\section{الــــلاصـــة}

أصبح الذكاء العاطفي ظاهره عالميه نظر الأثار بعيده المدى للأفراد و الجماعات و المجتمع ككل. وأصبح هام لإيجاد قائد ناجح. بالأضافه إلى أن القيادة الفعالة تلعب دور ا هاما في نمو وتحسين أداء المنظمة. وكان الهدف من وند هذه الدراسة تقييم العلاقة بين الذكاء العاطفي وأنماط القيادة لمشرفات التمريض في المستشفيات الحكومية ببورسعيد.تم استخدام در اسة تر ابطية وصفيه في هذه الدر اسة.أدوات هذه الدر اسة تتألف من مجمو عتين. مشرفات

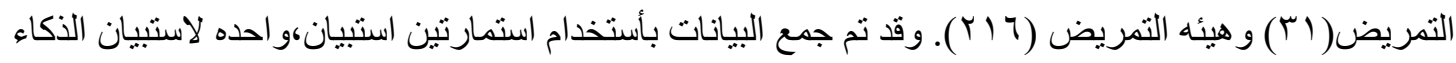

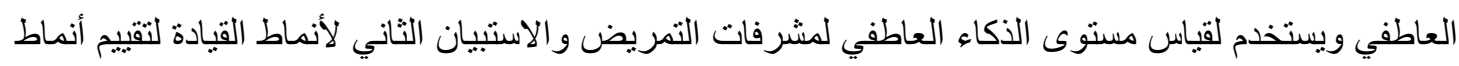
القيادة المستخدمة بواسطة مشرفات التمريض من وجهه نظر هيئه التمريض،بالأضافه إلى مخرجات القيادة

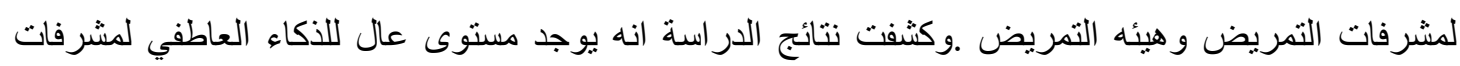
التمريض في المستشفيات الحكومية ببورسعيد و أنماط القيادة التحويلية سجلت أعلى منوسط بالنسبة لأنماط القيادة

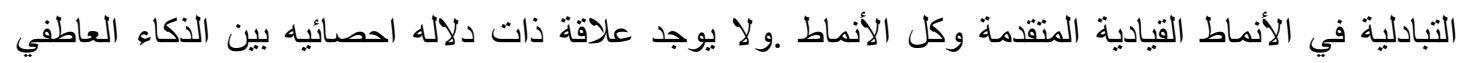

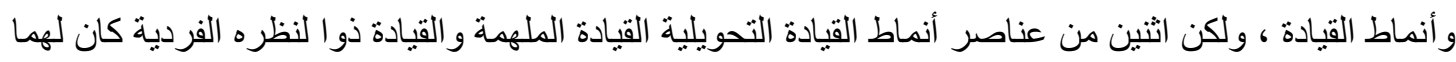
علاقة سلبيه إحصائيا مع الكفاءة الأجتماعيه بالأضافه إلى الكفاءة الثخصية وأجمالي الذكاء العاطفي للقيادة

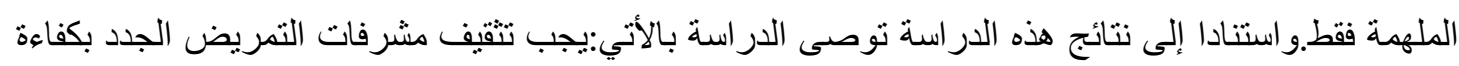
الذكاء العاطفي وكيفيه تحسين و عيهم به مع أنماط القيادة عن طريق منظمتهم. 